\title{
Hubungan Sanitasi Lingkungan Rumah dengan Kejadian Askariasis dan Trikuriasis pada Siswa SD N 29 Purus Padang
}

\author{
Hildya Kusmi ${ }^{1}$, Nuzulia Irawati², Husnil Kadri ${ }^{3}$
}

\begin{abstract}
Abstrak
Prevalensi infeksi kecacingan masih tinggi terutama pada anak usia sekolah dasar. Cacing yang sering menginfeksi yaitu Ascaris lumbricoides dan Trichuris trichiura. Infeksi ini erat kaitannya dengan masalah lingkungan, perilaku manusia dan manipulasi terhadap lingkungan. Tujuan penelitian adalah menentukan hubungan sanitasi lingkungan rumah yaitu kepemilikan jamban keluarga yang sehat, ketersediaan sumber air bersih, sarana pembuangan sampah dan jenis lantai rumah dengan kejadian askariasis dan trikuriasis. Ini adalah penelitian analitik dengan desain cross-sectional study. Jumlah populasi sebanyak 71 orang dengan jumlah subjek sebanyak 55 orang. Pengumpulan data dilakukan dengan pemeriksaan tinja dan kuesioner. Metode analisis data menggunakan uji chisquare. Hasil penelitian menunjukkan bahwa persentase infeksi kecacingan pada siswa SD Negeri 29 Purus Padang adalah 38\%, terdiri dari; infeksi Ascaris lumbricoides (33\%), Trichuris trichiura (9,1\%) dan infeksi kedua spesies (3,6\%). Hasil uji chi-square menunjukkan tidak ada hubungan yang bermakna antara kepemilikan jamban keluarga, ketersediaan sumber air bersih, kepemilikan sarana pembuangan sampah dan jenis lantai rumah dengan angka kejadian askariasis dan trikuriasis $(p>0,05)$. Masih tingginya infeksi kecacingan pada siswa sekolah dasar perlu perhatian yang lebih baik misalnya diadakannya program pemberantasan kecacingan baik oleh sekolah maupun petugas kesehatan setempat.
\end{abstract}

Kata kunci: infeksi kecacingan, sanitasi lingkungan, askariasis, trikuriasis

\begin{abstract}
Prevalence of worms infestation is still high, especially found among children at the elementary school age. Type of worms that often infect are Ascaris lumbricoides and Trichuris trichiura. The infection is related to environment issues, human behavior and manipulation of the environment. The objective of this study was to determine the relationship between environmental sanitation of home, consist of latrine ownership, availability of clean water source, garbage disposal facilities and the type of floor home to ascariasis and trichuriasis incidences. This was an analytic with cross sectional study design. The population were 71 students of State Elementery School 29 Purus Padang, but the subjecs were 55 students.. Research instruments were stool examination and questionnaire. Bivariate analysis was chi-square test. The results showed that the worm infection rate in student of Elementary School 29 Purus Padang was $38 \%$, consist of Ascaris lumbricoides infection (33\%), Trichuris trichiura infection (9.1\%) and infection of both species (3.6\%). The statistical test indicated no significant relationship between latrine ownership, availability of clean water source, garbage disposal facilities, and the type of floor home to the incidence of ascariasis and trichuriasis ( $p>$ 0.05). The high worm infection in elementary school students need better attention, like worm eradication program by the school and local health authorities.
\end{abstract}

Keywords: worm infestations, environmental sanitation, ascariasis, trichuriasis

Affiliasi penulis: 1 Pendidikan Dokter FK UNAND (Fakultas Kedokteran Universitas Andalas Padang), 2. Bagian Parasitologi FK UNAND, 3. Bagian Biokimia FK UNAND.
Korespondensi: Hildya Kusmi, Email: hildyakusmi@rocketmail.com Telp: 085263104648 


\section{PENDAHULUAN}

Indonesia sebagai negara berkembang masih menghadapi masalah kesehatan, terutama yang berkaitan dengan penyakit infeksi. Salah satu penyakit infeksi yang masih tinggi insidennya di Indonesia yaitu kecacingan. ${ }^{1}$ Masih tingginya kejadian infeksi cacing disebabkan oleh beberapa faktor yaitu Indonesia memiliki iklim tropis dengan kelembaban udara yang tinggi, tingkat sosial ekonomi masyarakat yang tidak merata dan kurangnya kesadaran menjaga sanitasi lingkungan serta higiene perorangan yang masih belum baik yang mendukung untuk terjadinya infeksi dan penularan cacing. ${ }^{2}$

Prevalensi kecacingan di Indonesia sekitar $58,5 \%$ yang terdiri dari $30,4 \%$ terinfeksi cacing gelang (Ascaris lumbricoides), 21,25\% cacing cambuk (Trichuris trichiura) serta 6,5\% terinfeksi cacing tambang (Necator americanus dan Ancylostoma duodenale). Tingginya prevalensi kecacingan tidak terlepas dari kondisi tanah Indonesia yang subur yang merupakan lingkungan yang paling disenangi cacing sebagai tempat berkembang biak, di samping itu tidak jarang masyarakat melihat cacing yang masih hidup keluar bersama tinja dan menganggap ini sebagai hal yang biasa, hal ini menunjukkan kurangnya perhatian masyarakat terhadap infeksi cacing ini. ${ }^{3}$ Kecacingan dapat ditemukan pada semua golongan umur, namun prevalensi tertinggi ditemukan pada anak balita dan usia sekolah dasar (60-80\%), terutama cacing Ascaris lumbricoides dan Trichuris trichiura yang cenderung menyerang anak-anak berusia 5-10 tahun yang merupakan usia anak sekolah dasar. ${ }^{4}$

Kecacingan jarang menyebabkan kematian, tetapi infeksi kronis pada anak-anak dapat menyebabkan menurunnya kondisi gizi dan kesehatan sehingga pertumbuhan terhambat. ${ }^{5}$

World Health Assembly pada tahun 2001 mendesak negara anggotanya untuk mengendalikan kesakitan dan kecacingan. ${ }^{6}$ Kenyataannya frekuensi kecacingan masih tinggi, hal ini disebabkan pencegahan dan pemberantasan terhadap kecacingan belum juga dapat dilakukan secara maksimal karena dampak yang ditimbulkan oleh kecacingan tidak terlihat secara langsung pada si anak sehingga luput dari perhatian orang tua. ${ }^{2}$
Kecacingan merupakan salah satu penyakit berbasis lingkungan. Penyakit ini sangat erat kaitannya dengan masalah lingkungan, perilaku manusia, dan manipulasinya terhadap lingkungan. ${ }^{7}$

Di Kota Padang, kesehatan lingkungan pemukiman masih belum memadai. Berdasarkan data terakhir di Kota Padang setelah gempa 30 September 2009 sekitar 9\% penduduk Kota Padang tidak mempunyai fasilitas pembuangan air limbah, dan $63,80 \%$ penduduk yang mempunyai septic tank sedangkan sisanya menggunakan kolam dan sungai sebagai sarana pembuangan air limbahnya. Di wilayah Kecamatan Padang Barat, sebagian besar memanfaatkan sungai sebagai tempat mandi, cuci dan kakus, menggunakan MCK yang tidak layak, membuang secara langsung di badan air, seperti saluran drainase, sungai dan laut, sehingga terjadi pelanggaran terhadap baku mutu atau pencemaran lingkungan. ${ }^{8}$

Purus merupakan salah satu keluharan pada Kecamatan Padang Barat dengan kondisi sanitasi yang sangat buruk. ${ }^{9}$ Hasil survey pendahuluan yang dilakukan terdapat banyak sekolah dasar yang ada di Kelurahan Purus salah satunya yaitu SD negeri 29 Purus. Hasil observasi mendapatkan kondisi lingkungan sekolah dan rumah di sekitarnya masih belum baik dimana sekolah dan rumah tepat berada di sepanjang saluran pembuangan yang sangat kotor, banyak sampah dan tidak terawat dan disana terlihat banyak anak-anak yang bermain di sekitar saluran pembuangan tersebut.

Berdasarkan hal-hal yang telah diuraikan di atas maka perlu untuk mengadakan penelitian untuk mengetahui hubungan kondisi sanitasi lingkungan rumah dengan kejadian Askariasis dan Trikuriasis di Sekolah Dasar Negeri 29 Purus Padang.

\section{METODE}

Penelitian dilakukan terhadap siswa SD Negeri 29 Purus dari Desember sampai Februari 2014. Subjek dalam penelitian didapatkan sebanyak 55 dari semua siswa yang memenuhi kriteria inklusi dan eksklusi. Instrumen penelitian yang digunakan adalah kuesioner dan pemeriksaan tinja di Laboratorium Parasitologi. Data yang diperoleh diuji secara 
komputerisasi dengan uji chi-square pada tingkat pemaknaan $p<0,05$.

\section{Hasil}

\section{Karakteristik Subjek Penelitian}

Jenis Kelamin laki-laki lebih banyak dibandingkan perempuan yaitu sebesar $54,54 \%$. Usia terbanyak sebagai responden yaitu pada golongan umur > 9-13 tahun dibandingkan golongan 6-9 tahun yaitu sebesar $58,21 \%$. Kelas responden terbanyak adalah siswa kelas 3 yaitu sebesar $21,81 \%$. Pekerjaan dari orang tua responden terbanyak sebagai buruh sebesar 49,09\%. Pendidikan

orang tua dari responden lebih banyak yang memiliki pendidikan terakhir SMA sebesar41,81\%.

\section{Analisis Hubungan Jamban Keluarga dengan Kejadian Askariasis dan Trikuriasis}

Responden yang terinfeksi cacing Ascaris lumbricoides pada Tabel 1 sebanyak 18 responden dan yang terinfeksi Trichuris trichiura sebanyak 5 responden.

Kepemilikan Jamban Keluarga sebagian besar responden memiliki jamban keluarga yaitu sebanyak 39 responden, sedangkan yang tidak memiliki jamban keluarga sebanyak 16 responden.

Ketersediaan sumber air bersih yang memenuhi syarat sebanyak 32 responden, sedangkan yang sumber air bersihnya masih belum memenuhi syarat sebanyak 23 responden.

Kepemilikan sarana pembuangan sampah sebanyak 9 responden, sedangkan yang tidak memiliki sarana pembuangan sampah sebanyak 46 responden.

Jenis lantai rumah yang kedap air yaitu sebanyak 47 responden dan yang memiliki jenis lantai rumah yang tidak kedap air yaitu sebanyak 8 responden.

Hubungan Kepemilikan Jamban dengan kejadian Askariasis dan Trikuriasis pada siswa SD Negeri 29 Purus Padang didapatkan $p=0,264$ ( $p>0,05)$ yangnberarti tidak ada hubungan antara jamban keluarga dengan kejadian askariasis pada siswa 29 Purus Padang.

Berdasarkan uji statistik antara hubungan kepemilikan jamban keluarga dengan kejadian trikuriasis pada siswa SD Negeri 29 Purus yang menjadi responden didapatkan $p=0,110 \quad(p>0,05)$ sehingga tidak terdapat hubungan antara jamban keluarga dengan kejadian trikuriasis pada siswa 29 Purus Padang.(Tabel 1)

Tabel 1. Hubungan jamban keluarga dengan kejadian askariasis dan trikuriasis pada siswa SD N 29 Purus Padang

\begin{tabular}{|c|c|c|c|c|c|c|c|}
\hline \multirow{3}{*}{$\begin{array}{l}\text { Jamban } \\
\text { Keluarga }\end{array}$} & \multicolumn{4}{|c|}{ Kejadian Askariasis } & \multirow{2}{*}{\multicolumn{2}{|c|}{ Total }} & \multirow{3}{*}{$\mathbf{p}$} \\
\hline & \multicolumn{2}{|c|}{ Positif } & \multicolumn{2}{|c|}{ Negatif } & & & \\
\hline & $f$ & $\%$ & $f$ & $\%$ & $\mathbf{N}$ & $\%$ & \\
\hline $\begin{array}{l}\text { Tidak } \\
\text { memiliki }\end{array}$ & 7 & 43,75 & 9 & 56,25 & 16 & 100 & 0,264 \\
\hline Memiliki & 11 & 28,20 & 28 & 71,80 & 39 & 100 & \\
\hline Total & 18 & 32,73 & 37 & 67,27 & 55 & 100 & \\
\hline \multirow{3}{*}{$\begin{array}{l}\text { Jamban } \\
\text { Keluarga }\end{array}$} & \multicolumn{4}{|c|}{ Kejadian Trikuriasis } & \multirow{2}{*}{\multicolumn{2}{|c|}{ Total }} & \\
\hline & \multicolumn{2}{|c|}{ Positif } & \multicolumn{2}{|c|}{ Negatif } & & & $p$ \\
\hline & f & $\%$ & $f$ & $\%$ & $\mathbf{N}$ & $\%$ & \\
\hline $\begin{array}{l}\text { Tidak } \\
\text { memiliki }\end{array}$ & 3 & 18,75 & 13 & 81,25 & 16 & 100 & 0,110 \\
\hline Memiliki & 2 & 5,13 & 37 & 94,87 & 39 & 100 & \\
\hline Total & 5 & 9,09 & 50 & 90,91 & 55 & 100 & \\
\hline
\end{tabular}

Hubungan Ketersediaan Sumber Air Bersih dengan Kejadian Askariasis dan Trikuriasis

Tabel 2. Hubungan sumber air bersih dengan kejadian askariasis dan trikuriasis pada siswa SD N 29 Purus

Padang

\begin{tabular}{|c|c|c|c|c|c|c|c|}
\hline \multirow{3}{*}{$\begin{array}{l}\text { Sumber } \\
\text { air bersih }\end{array}$} & \multicolumn{4}{|c|}{ Kejadian Askariasis } & \multirow{2}{*}{\multicolumn{2}{|c|}{ Total }} & \multirow{3}{*}{ p } \\
\hline & \multicolumn{2}{|c|}{ Positif } & \multicolumn{2}{|c|}{ Negatif } & & & \\
\hline & f & $\%$ & $f$ & $\%$ & $\mathbf{N}$ & $\%$ & \\
\hline $\begin{array}{l}\text { Tidak } \\
\text { memenuhi } \\
\text { syarat }\end{array}$ & 5 & 21,74 & 18 & 78,26 & 23 & 100 & \multirow{3}{*}{0,141} \\
\hline $\begin{array}{l}\text { Memenuhi } \\
\text { syarat }\end{array}$ & 13 & 40,63 & 19 & 59,37 & 32 & 100 & \\
\hline Total & 18 & 32,73 & 37 & 67,27 & 55 & 100 & \\
\hline \multirow{3}{*}{$\begin{array}{l}\text { Sumber } \\
\text { air bersih }\end{array}$} & \multicolumn{4}{|c|}{ Kejadian Trikuriasis } & \multirow{2}{*}{\multicolumn{2}{|c|}{ Total }} & \multirow{3}{*}{$\mathbf{p}$} \\
\hline & \multicolumn{2}{|c|}{ Positif } & \multicolumn{2}{|c|}{ Negatif } & & & \\
\hline & $f$ & $\%$ & $\mathbf{f}$ & $\%$ & $\mathbf{N}$ & $\%$ & \\
\hline $\begin{array}{l}\text { Tidak } \\
\text { memenuhi } \\
\text { syarat }\end{array}$ & 2 & 8,7 & 21 & 91,3 & 23 & 100 & 0,931 \\
\hline $\begin{array}{l}\text { Memenuhi } \\
\text { syarat }\end{array}$ & 3 & 9,37 & 29 & 90,63 & 32 & 100 & \\
\hline Total & 5 & 9,09 & 50 & 90,91 & 55 & 100 & \\
\hline
\end{tabular}


Berdasarkan uji statistik pada Tabel 2, antara ketersediaan sumber air bersih dengan kejadian askariasis pada siswa SD Negeri 29 Purus yang menjadi responden didapatkan $p=0,141$ ( $p>0,05)$. Hubungan ketersediaan sumber air bersih dengan kejadian trikuriasis pada siswa SD Negeri 29 Purus yang menjadi responden didapatkan $p=0,931 \quad(p>0,05)$ sehingga tidak ada hubungan antara ketersediaan sumber air bersih dengan kejadian askariasis pada siswa 29 Purus Padang.

Hubungan Sarana Pembuangan Sampah dengan kejadian askariasis dan trikuriasis pada siswa SD N 29 Purus Padang

Berdasarkan uji statistik pada Tabel 3, antara hubungan kepemilikan sarana pembuangan sampah dengan kejadian askariasis pada siswa SD Negeri 29 Purus yang menjadi responden didapatkan $p=0,463$ ( $p>0,05$ ) sehingga tidak ada hubungan antara kepemilikan sarana pembuangan sampah dengan kejadian askariasis pada siswa 29 Purus Padang.

Tabel 3. Hubungan sarana pembuangan sampah dengan kejadian askariasis dan trikuriasis pada siswa SD N 29 Purus Padang

\begin{tabular}{|c|c|c|c|c|c|c|c|}
\hline \multirow{3}{*}{$\begin{array}{c}\text { Sarana } \\
\text { pembuangan } \\
\text { sampah }\end{array}$} & \multicolumn{4}{|c|}{ Kejadian Trikuriasis } & \multirow{2}{*}{\multicolumn{2}{|c|}{ Total }} & \multirow{3}{*}{$\mathbf{p}$} \\
\hline & \multicolumn{2}{|c|}{ Positif } & \multicolumn{2}{|c|}{ Negatif } & & & \\
\hline & $f$ & $\%$ & $f$ & $\%$ & $\mathbf{N}$ & $\%$ & \\
\hline $\begin{array}{l}\text { Tidak } \\
\text { memiliki }\end{array}$ & 5 & 10,87 & 41 & 89,13 & 46 & 100 & 0,3 \\
\hline Memiliki & 0 & 0 & 9 & 100 & 9 & 100 & \\
\hline Total & 5 & 9,09 & 50 & 90,91 & 55 & 100 & \\
\hline
\end{tabular}

\begin{tabular}{|c|c|c|c|c|c|c|c|}
\hline \multirow{3}{*}{$\begin{array}{c}\text { Sarana } \\
\text { pembuangal } \\
\text { sampah }\end{array}$} & \multicolumn{4}{|c|}{ Kejadian Askariasis } & \multirow{2}{*}{\multicolumn{2}{|c|}{ Total }} & \multirow{3}{*}{$p$} \\
\hline & \multicolumn{2}{|c|}{ Positif } & \multicolumn{2}{|c|}{ Negatif } & & & \\
\hline & $f$ & $\%$ & $f$ & $\%$ & $\mathbf{N}$ & $\%$ & \\
\hline $\begin{array}{l}\text { Tidak } \\
\text { memiliki }\end{array}$ & 16 & 34,78 & 30 & 65,22 & 46 & 100 & \\
\hline Memiliki & 2 & 22,22 & 7 & 77,78 & 9 & 100 & 0,40 \\
\hline Total & 18 & 32,73 & 37 & 67,27 & 55 & 100 & \\
\hline
\end{tabular}

Hubungan kepemilikan sarana pembuangan sampah dengan kejadian trikuriasis pada siswa SD Negeri 29 Purus yang menjadi responden didapatkan $p=0,3(p>0,05)$ sehingga tidak ada hubungan antara kepemilikan sarana pembuangan sampah dengan kejadian trikuriasis pada siswa 29 Purus Padang.
Hubungan Jenis Lantai dengan Kejadian Askariasis dan Trikuriasis pada Siswa SD Negeri 29 Purus Padang

Berdasarkan uji statistik pada Tabel 4, antara hubungan jenis lantai rumah dengan kejadian askariasis pada siswa SD Negeri 29 Purus yang menjadi responden didapatkan $p=0,614(p>0,05)$ sehingga tidak ada hubungan antara jenis lantai rumah dengan kejadian askariasis pada siswa 29 Purus Padang.

Tabel 4. Hubungan jenis lantai rumah kejadian askariasis dan trikuriasis pada siswa SD N 29 Purus Padang

\begin{tabular}{|c|c|c|c|c|c|c|c|}
\hline \multirow{3}{*}{$\begin{array}{l}\text { Jenis } \\
\text { lantai }\end{array}$} & \multicolumn{4}{|c|}{ Kejadian Askariasis } & \multirow{2}{*}{\multicolumn{2}{|c|}{ Total }} & \multirow{3}{*}{$\mathbf{p}$} \\
\hline & \multicolumn{2}{|c|}{ Positif } & \multicolumn{2}{|c|}{ Negatif } & & & \\
\hline & $f$ & $\%$ & $f$ & $\%$ & $\mathbf{N}$ & $\%$ & \\
\hline $\begin{array}{l}\text { Tidak } \\
\text { kedap air }\end{array}$ & 2 & 25 & 6 & 75 & 8 & 100 & \\
\hline $\begin{array}{l}\text { Kedap } \\
\text { air }\end{array}$ & 16 & 34,04 & 31 & 65,96 & 47 & 100 & 0,614 \\
\hline Total & 18 & 32,73 & 37 & 67,27 & 55 & 100 & \\
\hline \multirow{3}{*}{$\begin{array}{l}\text { Jenis } \\
\text { lantai }\end{array}$} & \multicolumn{4}{|c|}{ Kejadian Trikuriasis } & \multirow{2}{*}{\multicolumn{2}{|c|}{ Total }} & \multirow{3}{*}{$\mathbf{p}$} \\
\hline & \multicolumn{2}{|c|}{ Positif } & \multicolumn{2}{|c|}{ Negatif } & & & \\
\hline & $f$ & $\%$ & $f$ & $\%$ & $\mathbf{N}$ & $\%$ & \\
\hline $\begin{array}{l}\text { Tidak } \\
\text { kedap air }\end{array}$ & 1 & 12,5 & 7 & 87,5 & 8 & 100 & 0,717 \\
\hline Kedap air & 4 & 8,51 & 43 & 91,49 & 47 & 100 & \\
\hline Total & 5 & 9,09 & 50 & 90,91 & 55 & 100 & \\
\hline
\end{tabular}

Hubungan jenis lantai rumah dengan kejadian trikuriasis pada siswa SD Negeri 29 Purus yang menjadi responden didapatkan $p=0,717$ ( $p>0,05)$, yang berarti tidak ada hubungan antara jenis lantai rumah dengan kejadian trikuriasis pada siswa 29 Purus Padang.

\section{PEMBAHASAN}

Hubungan Kepemilikan Jamban dengan Kejadian Askariasis dan Trikuriasis pada Siswa SD Negeri 29 Purus Padang

Hasil uji statistik menunjukkan bahwa tidak ada hubungan antara jamban keluarga dengan kejadian askariasis dan trikuriasis pada siswa 29 Purus Padang. Sedangkan penelitian yang dilakukan Kuandain et al (2011) pada murid sekolah dasar di Desa Teling Kecamatan Tombariri Kabupaten Minahasa menemukan tidak ada hubungan bermakna 
antara jamban dengan infeksi kecacingan $(p=$ $0,869) \cdot{ }^{10} \mathrm{Hal}$ ini berbeda dengan penelitian Fitri et al (2012) pada murid sekolah dasar di Kecamatan Angkola Timur Kabaupaten Tapanuli Selatan yang menemukan bahwa terdapat hubungan yang bermakna antara kepemilikan jamban dengan infeksi kecacingan $(p=0,00) .{ }^{11}$ Penelitian Nur et al (2013) pada siswa sekolah dasar di Pulau Barrang Lompo Kota Makasar juga menemukan adanya hubungan yang bermakna antara jamban keluarga dengan infeksi kecacingan $(p=0,00) .{ }^{12}$

Tidak ditemukannya hubungan antara kepemilikan jamban keluarga dengan kejadian askariasis dan trikuriasis pada siswa SD Negeri 29 Purus Padang bisa disebabkan adanya faktor lain yang tidak diteliti, seperti kebiasaan anak mencuci tangan mau makan dan setelah makan serta setelah buang air kecil maupun buang air besar sehingga tidak akan terjadi penularan dari cacing Ascaris lumbricoides dan Trichuris trichiura karena akan terputusnya rantai penularan dari satu individu ke individu lainnya.

\section{Hubungan Ketersediaan Sumber Air Bersih dengan Kejadian Askariasis dan Trikuriasis pada Siswa SD Negeri 29 Purus Padang}

Hasil uji statistik menunjukkan bahwa tidak ada hubungan antara ketersediaan sumber air bersih dengan kejadian askariasis dan trikuriasis pada siswa 29 Purus Padang. Penelitian yang dilakukan Kuandain et al (2011) pada murid sekolah dasar di Desa Teling Kecamatan Tombariri Kabupaten Minahasa menemukan tidak ada hubungan bermakna antara sumber air bersih dengan infeksi kecacingan ( $p=$ $0,869) .{ }^{10} \mathrm{Hal}$ ini berbeda dengan penelitian Fitri et al (2012) pada murid sekolah dasar di Kecamatan Angkola Timur Kabaupaten Tapanuli Selatan yang menemukan bahwa terdapat tidak ada hubungan yang bermakna antara ketersediaan sumber air bersih dengan infeksi kecacingan. ${ }^{11}$

Hal ini disebabkan karena adanya faktor lain yang juga berperan dalam menyebabkan seseorang terinfeksi cacing Ascaris lumbricoides dan Trichuris trichiura seperti status gizi seserang yang akan mempengaruhi mudah atau tidaknya seseorang terkena kecacingan.
Hubungan Kepemilikan Sarana Pembuangan Sampah dengan Kejadian Askariasis dan Trikuriasis pada Siswa SD Negeri 29 Purus Padang

Hasil uji statistik menunjukkan bahwa tidak ada hubungan antara kepemilikan sarana pembungan sampah dengan kejadian askariasisdan trikuriasis pada siswa 29 Purus Padang. Hal ini berbeda dengan penelitian Fitri et al (2012) pada murid sekolah dasar di Kecamatan Angkola Timur Kabaupaten Tapanuli Selatan yang menemukan bahwa terdapat hubungan yang bermakna antara kepemilikan sarana pembuangan sampah infeksi kecacingan. ${ }^{11}$ Penelitian Nur et al (2013) pada siswa sekolah dasar di Pulau Barrang Lompo Kota Makasar tahun menemukan adanya hubungan yang bermakna antara sarana pembuangan sampah dengan infeksi kecacingan $(p=$ $0,045) .^{12}$

Tidak ditemukannya hubungan antara kepemilikan sarana pembuangan sampah dengan kejadian askariasis dan trikuriasis mungkin saja disebabkan adanya faktor lain yang tidak diteliti namun memiliki peran dalam menyebabkan seseorang terkena kecacingan, seperti status gizi, kebersihan pribadi, pengetahuan orang tua terhadap sanitasi lingkungan sekitar sehingga si anak tidak mudah mengalami kecacingan.

\section{Hubungan Jenis Lantai dengan Kejadian Askariasis dan Trikuriasis pada Siswa SD Negeri 29 Purus Padang}

Hasil uji statistik menunjukkan bahwa tidak ada hubungan antara jenis lantai rumah dengan kejadian askariasis dan trikuriasis pada siswa 29 Purus Padang. Penelitian Nur et al (2013) pada siswa sekolah dasar di Pulau Barrang Lompo Kota Makasar menemukan tidak ada hubungan antara jenis lantai rumah dengan infeksi kecacingan $(p=0,147) \cdot{ }^{12}$ Penelitian yang dilakukan Kuandain et al (2011) pada murid sekolah dasar di Desa Teling Kecamatan Tombariri Kabupaten Minahasa menemukan tidak ada hubungan bermakna antara jenis lantai rumah dengan infeksi kecacingan $(p=0,077) \cdot{ }^{10}$

Hal ini mungkin disebabkan adanya faktor lain yang tidak diteliti namun memiliki peran dalam menyebabkan seseorang terkena kecacingan seperti status gizi, karakteristik siswa, perilaku siswa serta 
kebersihan pribadi sehingga si anak tidak mudah mengalami kecacingan.

\section{KESIMPULAN}

Tidak ada hubungan antara kepemilikan jamban keluarga dengan kejadian askariasis dan trikuriasis pada siswa 29 Purus Padang.

Tidak ada hubungan antara ketersediaan sumber air bersih dengan kejadian askariasis dan trikuriasis pada siswa 29 Purus Padang.

Tidak ada hubungan antara kepemilikan sarana pembuangan sampah dengan kejadian askariasis dan trikuriasis pada siswa 29 Purus Padang.

Tidak ada hubungan antara jenis lantai rumah dengan kejadian askariasis dan trikuriasis pada siswa 29 Purus Padang.

\section{UCAPAN TERIMA KASIH}

Ucapan terima kasih kepada semua pihak yang sudah membantuan dan motivasi penulis dalam penelitian ini.

\section{DAFTAR PUSTAKA}

1. Depkes RI. Pedoman umum program nasional pemberantasan cacing di era desentralisasi. Jakarta: Depkes RI; 2004.

2. Daichi RA. Hubungan perilaku anak terhadap infeksi cacing perut di sekolah dasar no.174593 Kecamatan Palipi Kabupaten Samosi. (diunduh 28 Juni 2013). Tersedia dari: URL: HYPERLINK http://repository.usu.ac.id/bitstream/123456789/15 363/1/mki-des2005-\%20\%285\%29.pdf

3. Rampengan TH. Penyakit infeksi tropik pada anak. Jakarta: EGC; 2008.

4. Supriastuti. Infeksi soil-transmitted helminth: ascariasis, trichiuriasis, dan cacing tambang. Universa Medicina. 2006; 25 (2):
5. Damayanti A. Pengobatan dan penilaian status gizi anak SDN 1 Luwus, Baturiti yang menderita cacingan. 2009 (diunduh 17 Juli 2013). Tersedia dari: URL: HYPERLINK http://ejournal.unud.ac.id/ abstrak/damayanti\%20090102010.pdf

6. World Health Organization. Prevention and control of schistosomiasis and soil-transmitted helmianthiasis. WHO Technical Report Series Report 912. Geneva: WHO; 2002

7. Lalandos JL, Kareri DGR. Prevalensi infeksi cacing usus yang ditularkan melalui tanah pada siswa SD GMIM Lahay Roy Malalayang. MKM. 2008; 3(2).

8. Dinas Kesehatan Koto Padang. Profil Dinkes Kota Padang. 2007 (diunduh 18 Juli 2013). Tersedia dari: URL: HYPERLINK http://www.depkes.go.id/ downloads/profil/kota padang 2007

9. Nelza W, Soedjono ES. Strategi pengelolaan air limbah perkotaan di Kota Padang, Studi kasus Kecamatan Padang Barat (tesis). Surabaya: Institut Teknik Surabaya; 2011.

10. Kuandain F, Umboh JML, Kepel BJ. Hubungan antara sanitasi lingkungan dengan infestasi cacing pada murid sekolah dasar di Desa Telling Kecamatan Tombariri Kabupaten Minahasa. Manado: Universitas Sam Ratulangi; 2011.

11. Fitri J, Saam Z, Hamidy MY. Analisis faktor-faktor risiko infeksi cacingan murid sekolah dasar di Kecamatan Angkola Timur Kabupaten Tapanuli Selatan tahun 2012. Jurnal IImu Lingkungan. Universitas Riau; 2012.

12. Nur MI, Ane RL, Selomo M. Faktor risiko sanitasi lingkungan rumag terhadap kejadian kecacingan pada murid sekolah dasar di Pulau Barrang Lompo Kota Makassar tahun 2013. Makasar: Universitas Hasanudin; 2013. 